\title{
Developments in and Influences on, Financial Reporting in UK
}

\author{
Yating Guo \\ Accounting and Finance Division, University of Stirling, Scotland, United Kingdom \\ Email address: \\ yag00011@students.stir.ac.uk
}

\section{To cite this article:}

Yating Guo. Developments in and Influences on, Financial Reporting in UK. Journal of Finance and Accounting. Vol. 3, No. 6, 2015, pp. 215-219. doi: 10.11648/j.jfa.20150306.17

\begin{abstract}
Accounting plays a very important role in society, it impacts on peoples' wealth and can be a source of power. This does not just apply in the private sector commercial context (consider accounting in other contexts: the public sector, e.g. hospitals and prisons, education, the military; religious institutions; private households, etc.). In addition, accounting information and performance indicators are not objective, absolute measures. Skill and judgment are required in preparing and interpreting accounting information. Thus, this paper will introduce the key developments and influences of the financial reporting in the UK. The research target of this report is the United Kingdom, and the destination is to determine some significant developments and its influences on financial reporting in UK. For this aim, the development of financial reporting from accounting standard and economic policy aspects should be involved, as well as few marked impact on the future of the UK. Relying on the effect of IFRS and Companies Act 2006, financial reporting has a strong transparency and enough reliability of standards to support its constant accounting system. It is foreseen, UK will continue to maintain its existing accounting standards and it will gradually reduce failure economic events in future.
\end{abstract}

Keywords: Financial Reporting, IFRS, Companies Act 2006, Company Law, New UK GAAP

\section{Introduction}

As the global crisis ended on the first decade of the $21 \mathrm{st}$ century, financial reporting has been concerned by more and more financial institutions and relevant professional person who work in this industry. This is because the main failures of these events are caused by the ability of the financial statement. Specifically, it is a failure of warning the users of risks. Therefore, financial reporting is an essential communication process. It should be abided by the change of international accounting standard issued by financial accounting standard board and some relevant economic policies.

The main body of this essay will discuss some significant developments and its influences on financial reporting. In development section, this essay will discuss the development of financial reporting from accounting standard and economic policy aspects. In influence section, it will analyse few marked impact on the future of the UK. Finally, some conclusions on how effective IFRS and company act 2006 is for financial reporting on this topic.

\section{Developments in Financial Reporting}

\subsection{Summary History of Accounting Environment in the United Kingdom}

The United Kingdom has many outstanding features in whole accounting environment and the UK can be regarded as a leader among Europe. These features are divided into three aspects: firstly, the UK has a strong and independent accounting profession. Secondly, it has professional regulators to make detailed accounting method which can meet the traditional legal requirements. Thirdly, it has strong connection with US accountants. They have a number of communicating between US and UK offices of the international accounting department. (John, Oriol, 1950)

There is some basic information for UK reporting environment to be listed on the form as follow: 
Table 1. UK reporting environment (Mair, 2008).

\begin{tabular}{lllll}
\hline Major sources of regulation & Legal system & Main users of annual reports & Basis of accounting & Economy and market structure \\
\hline Company law & & & & Large open economy \\
$\begin{array}{l}\text { Accounting standards } \\
\text { Stock exchange requirements }\end{array}$ & Common law & Investors & Accruals concept dominates & Well-developed capital market \\
Financial services authority & & & & \\
\hline
\end{tabular}

\subsection{International Accounting Standard}

The one of significant development for financial reporting is affected by accounting standard. There was a policy which issued by IAS regulation and adopted by European Union in July 2002, to issue "a directive requiring all listed companies of member states to prepare consolidated financial statements based on IFRS beginning January 1, 2005" (Mair, 2008). It was a significant change from adopting UK GAAP to IFRS. The UK had to adopt the IFRS instead of UK GAAP. According to Cairns (2004) states that the term 'IFRS' contains two parts, the first part of IFRS is issued by the IASB and the second part is that international accounting standards (IAS) issued by the IASC. Both of them controlled and revised by the IASB. Noticeable, there are difference purposes between the consolidated financial statements and individual accounts. Consolidated accounts reflect the purpose of the IASB's conceptual framework is to make useful decisions, however, individual accounts is related to tax, distributable reserves, dividend payments and regulatory purposes. (Stella el al, 2007)

UK accounting inclines to the significance of the management's stewardship before adopting IFRS whereas the IFRS are more focusing on valuation. Recently, the development of the fair value was steadily advanced. The balance sheet has been paying more attention to when developing the IFRS in the UK. UK GAAP has slight tendency to focus more on the income statement which present an obvious comparison to IFRS. (Stella el al, 2007)

IFRS is a more complete and more comprehensive accounting model than UK GAAP. IFRS is mainly used for those listed companies trading in the global capital markets. It not included the subsidiaries with a listed group; listed companies which are not part of a group; large unlisted companies; mutual firms; small and medium enterprises (SMEs); and public sector entities. (PWC,2012)

The second significant development of accounting standard is changing from IFRS to New UK GAAP. The financial reporting council revised financial reporting standards in the United Kingdom and republic of Ireland in 2012 and 2013. In addition, the new standard is implemented mandatorily starting on or after 1 January 2015, when all existing UK GAAP standards will be replaced by New UK GAAP issued by FRC. The revisions fundamentally reformed financial reporting, updating almost all extant standards with three financial reporting standards: FRS 100, FRS 101 and FRS 102. (PWC, 2012)

The new accounting standard could provide more choice and options for UK companies. It will not be difficult to determine if some companies would adapt to IFRS and New
UK GAAP which is the framework that has been reduced and FRSSE. However, for some of major companies, it should be carefully considered that which of the route should be taken as there are many options, and these options should be detailed figured out and weighted up. (PWC, 2012)

\subsection{Companies Act 2006}

The Companies Act 2006 plays a vital part in financial reporting and it received Royal Assent (UK Parliament) on 8 November 2006. The implementation of the Act is completed on 1 October 2009. It demonstrates a full modernization and comprehensive review of the UK company law framework. The Act provides numerous extraordinary changes to help company law being simplified and developed. It ensures the easy-understandable and flexible so that companies can have a better understanding and the financial reporting can be more straightforward. Furthermore, the Act will lead a favourable outcome. The primary goal of company act is to get more commitment and confidence from shareholder thereby acquire lone term investment that will help company decrease the burden of regulation moreover it also can contribute to operation and establishment.

UK, Holland and others countries set out rules for operations of companies in the leading place. The structure of corporate governance and company law give companies legally support for operation. It is a vital legal framework for conduction of corporations. It also increasingly aroused a great concern of the financial reporting.

The company law provisions of the 2006 Act (Parts 1 to 39) not merely restate almost all of the provisions of the 1985 Act, but also reiterate the company law clauses of the Companies Act 1989 (the 1989 Act). For connected purpose, it relates to the Companies (Audit, Investigations and Community Enterprise) Act 2004 (CAICE Act 2004). The company law provisions also codify certain aspects of the case law. In the Companies Acts, company means a company formed and registered under this Act, which including four types of company. For instance, private and public companies, limited and unlimited companies, companies limited by guarantee and having share capital and community interest companies (Steinfeld, 2007). However, with the development of business environment, there is a threat that the needs of companies might be separated from legal framework, especially the obstacles generated by smaller private businesses.

\section{Influences on Financial Reporting}

Referring to above developments in financial reporting, this paper is demonstrated its influences in the following. It 
can be separated into two parts: the first aspect is due to the changes of the accounting standards, and the rest point is about the influences caused by the economic events.

Considering the compulsory adoption of IFRS, it has impacts on the financial reporting in the UK. By compulsory adopting the IFRS in 2005, it can be described that it worked extraordinary well in the first year while some queries appeared afterwards (Fearnley et al., 2007). The financial statements display more up-to-date and accurate information for users than before, especially when FASB and IASB changed the way of financial statements presentation. The Statement of Financial Position provides a clearer format of the relationship among the assets, liabilities and equity. For users, it can be seen clear amounts of short-term and longterm figures. By separating this, the leverage ratio and other analysing method can be applied conveniently. Furthermore, more professional information is provided by adopting this method. Managers, investors and other users can forecast earnings and make budgets based on the financial reporting. Ball (2006) demonstrates that with the use of IFRS, the cost of handling the financial information decreased and these lead to the increase of efficiency. Investors can have the benefits from the increased market efficiency. The usefulness of financial decision can be a decent change for financial reporting part.

In the past, the national GAAP varies from countries to countries. There are many differences among different countries. This provides inconvenience and inappropriate regulation especially for multi-national corporations. This is also the main point for mandatory adoption of IFRS. It eliminates the international differences among countries. Considering the international harmonization, there is an interview made by Dunne (2008).

"Most interviewees agreed that the benefits of greater transparency, comparability and uniformity would only materialise in the medium to long-term".

The influence of this will be shown in further years as it is only applied for less than 10 years.

The transform from UK GAAP to International financial reporting has sparked much debate. Some people assert that IFRS is a standard with a high quality level that will make accounting practices become more harmonizes and transparency (Armstrong et al. 2009) while some other argue that compulsory execution IFRS may not get anticipate benefits however it base on pure accounting change and no effect from economic or after adoption may have lower quality (Watts 2006)

Through the above all and further investigation, Iatridis (2011) point out some voluntary disclosure find out after adoption IFRS they can offer a verifiability and validity of financial reporting to investors. Such as the firms will voluntary disclosures the information of accounting if firms with highly leveraged. Horton and Serafeim(2010) also provide evidence. There has significant impression from capital market because of through enhancement the quality of management information, corporate transparency and comparability between sectors and jurisdictions will change the perception of investors thereby decrease asymmetry of information and investors are provided with an effectively help to compare companies. Christensen, Lee and Walker (2007) mention reconciliations of IFRS result in significant market reaction on account of the IFRS reconciliations can provide more new information than had already been reported under UK GAAP Meanwhile Horton and Serafeim (2010) finding the main reason why IFRS become a reliable vehicle is it can reveal negative information. Before adoption IFRS, manager usually convey good news for get positive adjustments to earnings of UK GAAP. However some firms argue that they think effects of capital market more likely to be inappreciable as there no any additional benefits if firms compliance IFRS.

Nevertheless some people think IFRS reconciliations maybe cannot surprise the market, first they believe the disclosure quality of UK GAAP equal to or perhaps even better than IFRS. Secondly some manager point out investment decisions will affect the numbers of IFRS. Finally as mention earlier adjustments without cash flow implications when they are assumed to be pure accounting translations. (Horton and Serafeim, 2010)

With the numerous changes in the UK economic environment in 21 st century, it also changed the information requirements of financial reporting users, this expanded financial report content. However, the partnership and sole trader accounts have no specific legal rules in the Companies Act or other regulations. This implies that managers and owners of these businesses may change the accounting records to satisfy their needs and make accounts whenever they want. If these companies have registered for Value Added Tax, there is a need to keep up-to-date records for requirements of Her Majesty's Revenue and Customs. Moreover, owners of a business have to add any profits based on their personal income tax return as well. In this circumstance, most companies need to leave some basic accounting records and to make the elementary profit and loss account yearly. The choices of what kind of form or content for recording accounts are made by themselves.

To sum up, the Companies Act 2006 influences plenty accounting events.it is concerned with companies and limited liability partnerships. There are many details of reporting and preparation which relates to financial statements is delegated by this Companies Act to IASB and the UK Accounting Standards Board (for other companies). Therefore, the company has to make its accounts and operations as transparent as possible.

The NEW UK GAAP has been raised since 2012. It is used for the UK and the Ireland as well. Among the three standards, FRS 102 should be the most important one. Based on a finding from Guglielmi (2013), it demonstrates that half of Irish companies considered adopting the NEW UK GAAP will lead to a remarkable influence to the companies. Guglielmi (2013) also mention that $34 \%$ of companies considering to adopt it before the mandatory deadline. It can be projected that some companies acknowledge the usefulness and practical-applicability. By adopting FRS 102, 
the profits amount might be changed as the different treatment of tax charge and dividends payments.

When comes to talk about economic influence on financial reporting, there is a news published on PWC website. The UK government should pay more attention to the environmental production. In order to achieve this strategy, the UK treasure makes a change on disclosure which means that the financial reporting should include carbon emissions, waste and the use of finite resources. Although this is a slight change, it could reflect the financial reporting is close to economic activity.

\section{Conclusion}

In conclusion, this paper has introduced the key developments and influences of the financial reporting in the UK. The processes of accounting standards have changed from UK GAAP to IFRS, then transfers to the NEW UK GAAP. Through the investigation of IFRS, it could be found that it can standardise and systematize accounting standards in the UK. And also could develop the transparency and reliability of standards. In addition, the Companies Act 2006 reformed and simplified company law. It is easier to understand and more flexible for enterprises than before. For because New UK GAAP could provide the more specified and concise rules for UK. Therefore, financial reporting is so important although it still exist some problems to lead the New UK GAAP, it is more fit to UK accounting system. It is

failure. Its advantage is more than its disadvantage. Financial reporting is not only the important signal to warn people finding problems, but also it is an essential reporting to keep the companies operation in normal level. As the constant improvement of accounting system, financial reporting in the UK would become much better and reduce failure economic events as soon as possible in the future.

\section{Appendix 1:}

Complete set of financial statements

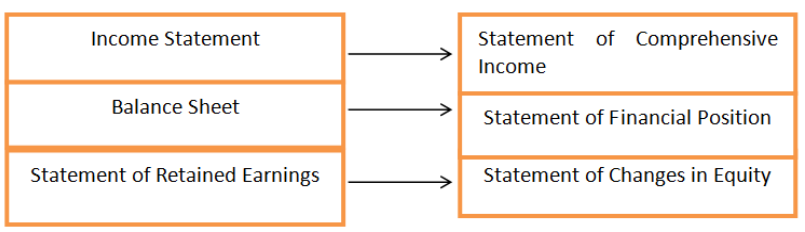

\section{Appendix 2:}

\section{NEW UK GAAP}
FRS 100
Application of Financial Reporting
FRS 101 Reduced Disclosure Framework
FRS 102 The Financial Reporting Standard Applicable in the UK and Republic of Ireland

\section{Appendix 3:}

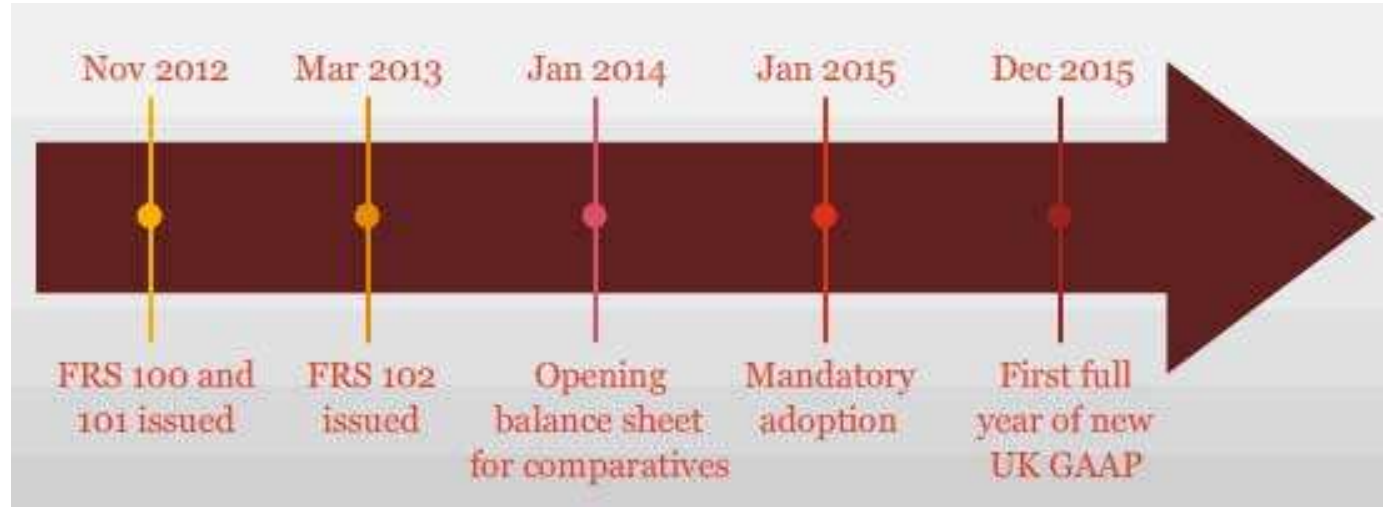

[5] CHRISTENSEN, H.B., LEE, E. and WALKER, M., 2007. Cross-sectional variation in the economic consequences of international accounting harmonization: The case of mandatory IFRS adoption in the UK. International Journal of Accounting, 12, vol. 42, no. 4, pp. 341-379.

[1] ARMSTRONG, C., 2006. Market Reaction to Events Surrounding the Adoption of IFRS in Europe.

[2] BALL, R., 2006. International Financial Reporting Standards (IFRS): pros and cons for investors. Accounting \& Business Research (Wolters Kluwer UK), 12/02, vol. 36, pp. 5-27.

[3] BENZACAR, K., 2009. IFRS brings a radical change to financial statement presentation. (cover story). CMA Management, 02, vol. 82, no. 9, pp. 28-33.

[4] CHRISTENSEN, H.B., LEE, E. and WALKER, M., 2007. Do IFRS/UK-GAAP reconciliations convey new information? SSRN eLibrary, Available at: Http://ssrn.com/paper $1 / 4997800$.
[6] FEARNLEY, S. and HINES, T., 2007. How IFRS has destabilised financial reporting for UK non-listed entities. Journal of Financial Regulation \& Compliance, 11, vol. 15, no. 4, pp. 394-408.

[7] GEE, M., HALLER, A. and NOBES, C., 2010. The Influence of Tax on IFRS Consolidated Statements: The Convergence of Germany and the UK. Accounting in Europe, 06, vol. 7, no. 1, pp. $97-122$.

[8] GORNIK-TOMASZEWSKI, S., 2006. New International Standard for Disclosures of Financial Instruments. Bank Accounting \& Finance (08943958), 02, vol. 19, no. 2, pp. 43-44. 
[9] GUGLIELMI, T., 2013. Watching the GAAP. Accountancy Ireland, 08, vol. 45, no. 4, pp. 57-57.

[10] HACKETT, F., 2013. White Smoke on New GAAP. Accountancy Ireland, 04, vol. 45, no. 2, pp. 7-10.

[11] HALLER, A. and WEHRFRITZ, M., 2013. The impact of national GAAP and accounting traditions on IFRS policy selection: Evidence from Germany and the UK. Journal of International Accounting, Auditing \& Taxation, vol. 22, no. 1, pp. 39-56.

[12] HORTON, J. and SERAFEIM, G., 2010. Market reaction to and valuation of IFRS reconciliation adjustments: first evidence from the UK. Review of Accounting Studies, 12, vol. 15 , no. 4 , pp. 725-751.

[13] IATRIDIS, G.E., 2012. Voluntary IFRS disclosures: evidence from the transition from UK GAAP to IFRSs. Managerial Auditing Journal, vol. 27, no. 6, pp. 573-597.
[14] NOBES, C., 2006. The survival of international differences under IFRS: towards a research agenda. Accounting \& Business Research (Wolters Kluwer UK), 09, vol. 36, no. 3, pp. 233-245.

[15] O'CALLAGHAN, I. and REYNOLDS, C., 2008. Bookshelf. Accountancy Ireland, 12, vol. 40, no. 6, pp. 86-86.

[16] PWC. 2013. Is new UK GAAP right for you?. [online] Available at: http://www.pwc.co.uk/audit-assurance/is-newuk-gaap-right-for-you.jhtml [Accessed: 12 Nov 2013].

[17] STEINFIELD, A. 2007. Blackstone's guide to the Companies Act 2006. Oxford: University Press.

[18] STERLING, R.R., 2003. A Patch on GAAP. Wiley-Blackwell, 10

[19] WATTS, R.L. 2006, "What has the invisible hand achieved?", Accounting and Business Research, vol. 36, no. sup1, pp. 51-61. 